\title{
CONSUMER CULTURE IN A POST-POSTMODERN WORLD
}

\author{
Bernard Cova
}

\section{Saturation of the postmodern}

The concepts of postmodern culture, postmodernism and postmodernity incited new perspectives and debates across many disciplines in the social sciences, humanities, and even physical sciences. Entering consumer and marketing research in the early 1990s, they stimulated questions about all marketing theory (Brown, 1999) and consumer research (Sherry, 1991; Firat and Venkatesh, 1995) that make a lasting impact on our field. Two broad marketing schools of thought emerged around the social changes characterized by the label of postmodern. The European school was heavily influenced by Maffesoli's ideas of neo-tribalism and emphasised the social links and communities made possible through consumption (Cova, 1997). In contrast, North American theorizing highlighted the increasing individualized consumer freed from traditional status markers such as class (Firat and Dholakia, 1998). Both perspectives, however, delineated how a new kind of paradoxical consumer emerged from the sociocultural ferment in the transformative shifts from modernity to postmodernity, a productive consumer, creating and communicating meanings through goods and services. This idea of the productive consumer was especially far-reaching and introduced for the first time the notion of consumers creating value as well as marketers. Indeed, sometimes this value creation could be in opposition to marketers, i.e. whenever meanings were appropriated and changed by consumers from those intended. Many new methodological approaches were introduced into consumer research to understand these processes of meaning creation; hermeneutics, phenomenology, semiotics, semiology and ethnography to name but a few of the leading ones. Thus, during the 1990 's and the beginning of the 2000's, the postmodern - postmodernism 
and postmodernity - played a major emancipatory role by revealing the socio-cultural processes at work in consumption activities.

Ideas take many years to migrate from the edge to the centre of academic disciplines. Through the development of the CCT or Consumer Culture Theory (Arnould and Thompson, 2005), cultural perspectives and their application to wider marketing management have gained more mainstream recognition (Penaloza, Toulouse and Visconti, 2012). Now, for example, the notion of consumer co-creation of value in goods and services, mentioned above, and the concomitant idea of mass customization, are widely accepted in mainstream marketing and consumer research circles and stem directly from the postmodern collapsing of production/consumption binaries and the foregrounding of the consumer as a meaning-making subject. Similarly, hermeneutic and semiotic approaches are widely used in more mainstream marketing research. It seems, therefore, more than pure coincidence that, soon after the publication of the setting up of CCT (Arnould and Thompson, 2005), the postmodern vanished into obscurity, taking with it the more critical edge to cultural perspectives. This is despite two noteworthy articles (Brown, 2006; Firat and Dholakia, 2006) that detailed how the postmodern had contributed to "problematize" the nature of marketing practice, marketing theory, marketing organizations, and marketing relationships and how it had fostered major changes in consumer research. In many ways these two papers (Brown, 2006; Firat and Dholakia, 2006) acted as death certificates of the postmodern in consumer research. It seems that with the birth of the CCT in order to establish a stronger branding and institutional recognition (particularly in the US) for the loosely-knit community of postmodern scholars, the emphasis put on the postmodern turn and its relevance for mainstream scholarship overshadowed the more radical nature of many postmodern contributions and took them backstage.

The movement of postmodern ideas into mainstream marketing marked their saturation in consumer research. As Sorokin (1937) explains, a cultural process reaches its "point of saturation" and then reverses its movement. The source of this cultural variation, in Sorokin's view, is primarily the "principle of immanent change" rather than external causation. Incessant change is an inherent consequence of the existence and activities of a cultural system. Indeed, while celebrating postmodern contributions to consumer and marketing research, some researchers have also pinpointed its limitations (from Holt, 2002, to Maclaran, 2009, including Goulding, 2003, and others). These critiques can usefully be summarised as follows (Tadajewski, 2010):

- We cannot really say that the contemporary world is more postmodern when the modernity's two main organizing forces - capitalism and bureaucratic power - are still dominating in western societies. Thus the concept of hypermodernity seems more suited to represent our condi- 
tion.

- Because postmodernism can be seen as the 'cultural arm' of multinational capitalism, its role is to reinforce a neo-conservative way of living that is environmentally unsustainable.

- Postmodernism is not necessarily appropriate for globalization. Postmodernity and postmodernism are social traits of the privileged part of the world and they depend on the high degree of consumption and affluence which is typical of this part of the world. It cannot be simply be made into everybody's way of life.

\section{Postpostmodernism?}

"The fateful question for our time is what comes after post-modernism, what comes after the after?" (Block, 2009). Turning to debates in the wider social sciences, Berger (2012) recently summarised the overall implications for postmodernism by arguing that we are faced with several alternative ways of thinking about it: that postmodernism existed and still exists; that modernism morphed into what we call postmodernism; that postmodernism never existed; or that it was just a ploy by clever French theorists to critique American culture. So perhaps the best way to make sense of what is happening is to argue that although postmodernism is still there, it is no longer the leading-edge thought. For example, Kirby (2009) highlights how postmodern assumptions still underpin Internet design and many elements of popular culture such as the writings of Jasper Fforde who blends science fiction, fantasy, literature, horror and romance. Kirby also acknowledges, however, that the heyday of postmodernism is over and, although its cultural traces can still be see, it no longer brings the strongest insights to understand the world in which we live. Similarly, Vermeulen and van der Akker (2010, p. 4) refer to "a new 'sens', a new meaning and direction" arising from the ashes of postmodernism.

So if postmodernism is over, then how can we refer to the present moment? A handful of terms have been suggested to label the trends that allegedly come after postmodernism (Boje, 2011), such as hypermodernism, metamodernism, altermodernism, etc. None of these terms, however, is as popular as that of 'post-postmodernism', which appears to function as a useful - if not unproblematic - shorthand for what is understood as a turn away from postmodernism. Even though postpostmodernism is an unwieldy term, faintly ridiculous with its two 'posts', judging from its increasingly frequent use, it may very well establish itself even before its meaning is well defined. Significantly, Nealon (2012) sees the 'post' as indicating continued links to postmodernism, a recognition of postmodernism's mutation rather than annihilation and its becoming something dif- 
ferent. Nealon (2012) points to a group of European theorists who have avoided jumping on the scholarly bandwagon in search of a new term, but who also claim that "postmodernism is already half obsolete" (Zizek, 2010, p. 246) and salute the reawakening of history (Badiou, 2012).

\section{Traces of postpostmodernism in today consumer research}

Reflecting on and synthetizing the various perspectives put forward, there are certain common characteristics that emerge as differentiating post-postmodern positions from postmodernism (Fjellestad and Engberg, 2012) both in society and in research.

Enthusiasm: a new type of enthusiasm is evident in post-postmodernity that counters postmodern apathy and the tendency to be nihilistic (Vermeulen and can den Akker, 2010), an enthusiasm that brings renewed hope in reconstruction rather than deconstruction. While postmodernism tended to be described in terms of unmaking, such as deconstruction, today's discourses are saturated with terms of re-making. "This change of prefixes from "de-" to "re-" marks a shift from the stance of negativity and opposition, of tearing matters apart to that of stitching things back together, of going back to previously held positions and convictions to revive and reconfigure them" (Fjellestad and Engberg, 2012). If we consider postpostmodernism as a postdeconstructive approach to theory in which deconstruction cannot be longer an excuse for inaction or withdrawal, then, in the realm of consumer research, the very idea of creating the CCT can be considered as a postpostmodern act, a kind of 'manifesto' (Bode and Ostergaard, 2012). The gathering of fragmented pieces resulting from the deconstruction of previously dominant theories in consumer research into a coherent whole could be considered as an act of reconfiguration, recombination, reorganization, etc., thus an act of reconstruction with a clear engagement of its two initiators (Arnould and Thompson, 2005) to convince those in the power position in the marketing discipline to recognize CCT as a legitimate stream of research (Bode and Ostergaard, 2012). Additionally, Arnould and Thompson's 2005 paper includes an explicit critique of the postmodernist antitotalization mode of thinking even if the authors' claim is not to build a grand theory but to maintain a certain plurality of perspectives.

Sincerity: Post-postmodern perspectives believe in something and represent a new earnestness that turns away from postmodern irony and pastiche to a more realist worldview that arises out of world events such as 9/11 and the financial crisis. According to recent cultural studies (Corona, 2012), there is a character who embodies the best postpostmodern sincerity, Lady Gaga! Lady Gaga represents many postmodern tropes that, for 
many, make her the inheritor of the Madonna lineage. However, when for Madonna, performance is about professionalism - slick, perfect, ironic and managed -, for Lady Gaga, it's about blood and guts, stumbles and falls, life and death (Fjellestad and Engberg, 2012). Lady Gaga is 'always on stage', living sincerely her art, grafting it into the visceral immediacy of life rather than playing with ironic citation and distance. The emergent TCR, Transformative Consumer Research, stream shows clear signs of sincerity and engagement. It distances itself from postmodern irony to shows more solemnity, and seriousness in its aims. Its mission is to foster research on quality of life that is both rigorous and applied for better assisting consumers, their caregivers, policy administrators, and executives. It is a devoted engagement with consumers and society, to address problems and opportunities of wellbeing, mainly arisen out of world events such as 9/11 and the financial crisis, "in a manner that speaks of shared values, empathy, immediacy, and usefulness" (Mick et al., 2011, p. 11). This leads consumer researchers not just to produce studies strictly for the academic community, i.e. to consider the impact of their work beyond measuring how much their work is cited by other colleagues: "TCR endorses a new role and image for consumer researchers as advocates for, and close partners with, consumers... TCR investigators are committed to a role of public servant" (Mick et al., 2011, p. 8). However, this does not mean a revolution in their epistemology and methodology. Cultural dimensions of the epistemology and the methodology remain the same, e.g. postmodern tropes, but in the service of a return to a knowing, wise, reformed sincerity and with an attention to public goods (Visconti et al., 2010).

Intermediality: As opposed to reinforcing a sense of postmodern fragmentation or Foucauldian panopticon, the blended and multiple technological environment plays a more beneficient role in post-postmodernism, facilitating a sharing ethos (through blogging, tweeting, Youtube, social networking sites etc) that makes it impossible to separate the cultural from the technological (Kirby, 2009). This allows for a new type of textuality that is multiple-authored and de-institutionalized in relation to both creation and production. We experience "our everyday lives as digital and multimedia 'bricoleurs', 'flaneurs' and disenfranchised 'poachers' left over from the post-postmodern remix of web 2.0" (Pederson, 2011). Thus, the terminology of 'interactivity' is deemed less and less appropriate (Kirby, 2006), since there is no exchange: instead, the viewer or listener enters - writes a segment of the programme - then departs, returning to a passive role. Recent research accounts for an everyday life which is characterized by decentralizations of and movement between intention and trace, mark maker and interpreter, reading and authorship, consumption and production, etc. (Belk and Tumbat, 2005; Rokka, 2010). This is especially true when it 
comes to online activities (Cammaerts, 2011; Giesler, 2006). It is impossible to distinguish the parties involved. This has created the need to investigate alternative paradigms for consumer research in order to understand consumption. Economic exchange and gift giving are both interaction-related paradigms which are not able to recognize the subtleties created by intermediality. Thus, the recent claim of Belk $(2007,2010)$ for the introduction of a sharing paradigm in consumer research has received attention and support from many colleagues: "A sense of collaborative ownership, like viewing the Internet as a commons... With such a wealth of resources available, it is understandable that some of us may want to offer our own contributions to unseen others who share our interests. The comedy of the commons view here is that of an expanding aggregate extended self that encourages a sense of sharing in" (Belk, 2010, p. 727).

During the last decade, the field of consumer research has not been without changes that can be connected to the above discussed postpostmodern characteristics. All together they highlight traces of postpostmodernism in today consumer research: 1) a renewed enthusiasm for theory (re)construction with the CCT; 2) a sincere engagement in the society with the emergence of TCR; 3 ) a paradigm shift in the way to look at consumption with the concept of sharing. At stake is the possibility of rejuvenating consumer research again and to open it up to new agenda of ethics and possibility previously unimaginable (Cova, Maclaran and Bradshaw, 2013).

\section{References}

Arnould E. and Thompson C.J. (2005). Consumer Culture Theory (CCT): Twenty Years of Research. Journal of Consumer Research, 31, 4: 868-882. Doi: $10.1086 / 426626$.

Badiou A. (2012). The Rebirth of History: Times of Riots and Uprisings. Verso: London. Berger A.A. (2012). The Day the World Changed: A Pomo Primer. Society, 49, 4: 317-322. Doi: 10.1007/S12115-012-9554-8.

Belk R.W. (2007). Why Not Share Rather than Own? Annals of the American Academy of Political and Social Science, 611, May: 126-140. Doi: 10.1177/0002716206298483.

Belk R.W. (2010). Sharing. Journal of Consumer Research, 36, 715-736. Doi: $10.1086 / 612649$.

Belk R.W. and Tumbat G. (2005). The Cult of Mac. Consumption, Markets and Culture, 8: 205-218. Doi: 10.10180/10253860500160403.

Block J. (2009). After post-modernism: Toward the recovery of theory. In: Dahms H.F. (ed.), Nature, Knowledge and Negation (Current Perspectives in Social Theory, Volume 26). Emerald Group Publishing Limited, 339-345.

Bode M. and Ostegaard P. (2012). The Wild and Wacky Worlds of Consumer Oddballs. Analysing the Manifestary Context of Consumer Culture Theory. Comunication at the CCT Conference, Oxford, August. 
Boje D.M. (2011). Theorizing after the Postmodern. In Catherine Cassell and Bill Lee, (eds.), Challenges and Controversies in Management Research. New York and London: Routledge, 389-403.

Brown S. (1999). Postmodernism: The End of Marketing. In Brownlie, Douglas, Mike Saren, Robin Wensley and Richard Whittington, eds. Rethinking Marketing. Towards Critical Marketing Accountings. London: Sage, 27-57.

Brown S. (2006). Recycling Postmodern Marketing. Irish Marketing Review, 6, 3 : 211-230. Doi: 10.1362/146934706778605322.

Cammaerts B. (2011). Disruptive Sharing in a Digital Age: Rejecting Neoliberalism?. Journal of Media and Cultural Studies, 25, 1: 47-62. Doi: 10.1080/10304312.2011.539157.

Corona V.P. (2012). Memory, Monsters, and Lady Gaga. Journal of Popular Culture, 44, 2: 1-19.

Cova B. (1997). Community and Consumption: Towards a Definition of the Linking Value of Products or Services. European Journal of Marketing, 31, 3/4: 297-316. Doi: $10.1108 / 93090569710162380$.

Cova B., Maclaran P. and Bradshaw A. (2013). Rethinking Consumer Culture Theory from the Postmodern to the Communist Horizon. Marketing Theory, 13, 2: 213225. Doi: $101177 / 1470593113477890$.

Firat A. Fuat and Nikilesh Dholakia (1998). Consuming People: From Political Economy to Theaters of Consumption. Sage: London.

Firat A. F. and Dholakia N. (2006). Theoretical and Philosophical Implications of Postmodern Debates: Some Challenges to Modern Marketing. Marketing Theory, 6, 2: 123-162. Doi: 10.1177/1470593106063981.

Firat A. F. and Venkatesh A. (1995). Liberatory Postmodernism and the Reenchantment of Consumption. Journal of Consumer Research, 22, December: 239-267.

Fjellestad D. and Engberg M. (2012). Toward a Concept of Post-Postmodernism or Lady Gaga's Reconfigurations of Madonna. Reconstruction: Studies in Contemporary Culture, Reconstruction, 12, 4, http://reconstruction.eserver.org/124/Fjellestad-Engberg.shtml.

Giesler M. (2006). Consumer Gift System: Netnographic Insights from Napster. Journal of Consumer Research, 33: 283-90. Doi: 10.1086/506309.

Goulding C. (2003). Issues in Representing the Postmodern Consumer. Qualitative Market Research: An International Journal, 6, 3: 152-159. Doi: $10.1108 / 13522750310478985$.

Holt D.B. (2002). Why do brands cause trouble? a dialectical theory of consumer culture and branding. Journal of Consumer Research, 29, 1: 70-90. Doi: $10.1086 / 339922$.

Kirby A. (2006). The Death of Postmodernism and Beyond. Philosophy Now, 58, Nov./Dec.

Kirby A. (2009). Digimodernism: How New Technologies Dismantle the Postmodern and Reconfigure Our Culture. London/New York: Continuum.

Maclaran P. (2009). Postmodernism and Beyond. In: Parsons E. and Maclaran P., eds., Contemporary Issues in Marketing and Consumer Research. London: Elsevier/Butterworth-Heinemann, 37-54.

Mick D.G., Pettigrew S., Pechmann C. and Ozanne J.L. (2011). Origins, Qualities, and Envisionments of Transformative Consumer Research. In: Mick D.G., Pettigrew S., Pechmann C. and Ozanne J.L., eds., Transformative Consumer Research for Personal and Collective Well-Being. New York: Routledge, 3-24. 
Nealon J.T. (2012). Post-Postmodernism or, The Cultural Logic of Just-in-Time Capitalism. Stanford: Stanford University Press.

Pederson J. (2011). Metamodernism in Fashion and Style Practice: Authorship and the Consumer. $3^{\text {rd }}$ Global Conference on Fashion: Exploring Critical Issues, Oxford, Sept.

Penaloza L., Toulouse N. and Visconti L.M., eds. (2012). Marketing Management: A Cultural Perspective. London/New York: Routledge.

Rokka J. (2010). Netnographic Inquiry and New Translocal Sites of the Social. International Journal of Consumer Studies, 34, 4: 381-387. Doi: 10.1111/J.14706431.2010.00877.X.

Sherry J.F. Jr. (1991). Postmodern Alternatives: The Interpretive Turn in Consumer Research. In: Robertson T.C. and Kassarjian H.H., eds., Handbook of Consumer Research. Englewood Cliffs: Prentice-Hall, 548-591.

Sorokin P.A. (1937). Social and Cultural Dynamics. A Study of Change in Major Systems of Art, Truth, Ethics, Law and Social Relationships (Four Volumes), New York: Bedminster Press.

Tadajewski M. (2010). Towards a history of critical marketing studies. Journal of Marketing Management, 26, 9/10: 773-824.

Vermeulen T. and Van Den Akker R. (2010). Notes on Metamodernism. Journal of Aesthetics \& Culture, 2. Doi: 10.3402/jac.v1i0.5677.

Visconti L.M., Sherry J.F. Jr., Borghini S. and Anderson L. (2010). Street Art, Sweet Art: The Reclamation of Public Place. Journal of Consumer Research, 37, 3: 511529. Doi: 10.1086/652731.

Zizek S. (2010). Living in the End Times, London: Verso. 